〔原著論文〕

\title{
口之島牛集団における経済形質、遺伝性疾患および毛色に関連する 遺伝子の対立遺伝子頻度とその分布
}

\author{
斯琴図雅 1 、西牧 孝洋 1 、揖斐 隆之 2 、过 岳人 2 、米田 一裕 3 、大島 一郎 4 、 \\ 片平 清美 4、万年 英之 5 、下桐 猛 4、印牧 美佐生 6 、国枝 哲夫 2 \\ 1 岡山大学大学院自然科学研究科 $\bar{T} 700-8530$ 岡山県岡山市北区津島中 1-1-1 \\ 2 岡山大学大学院環境生命科学研究科 $\bar{T} 700-8530$ 岡山県岡山市北区津島中 1-1-1 \\ 3 米田遺伝子型研究所 $\overline{\mathrm{T}} 569-1017$ 大阪府高柣市成合北の町 774-2 \\ 4 鹿児島大学農学部 ₹ 890-0065 鹿児島県鹿児島市郡元 1-21-24 \\ 5 神戸大学大学院農学研究科 T 657-0013 兵庫県神戸市灘区六甲台町 1-1

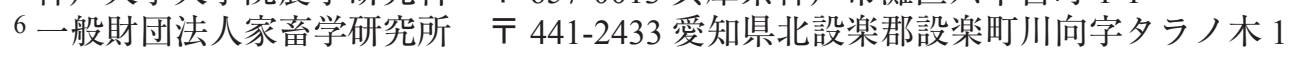

\section{Allelic distributions of genes involved in economical traits, hereditary disorder, and coat color in a population of Kuchinoshima cattle}

\author{
SIQINTUYA ${ }^{1}$, Takahiro NISHIMAKI ${ }^{1}$, Takayuki IBI ${ }^{2}$, Takehito, TSUJI ${ }^{2}$, Kazuhiro YONEDA ${ }^{3}$, \\ Ichiro OSHIMA ${ }^{4}$, Kiyomi KATAHIRA ${ }^{4}$, Hideyuki MANNEN ${ }^{5}$, Takeshi SHIMOGIRI ${ }^{4}$, \\ Misao KANEMAKI ${ }^{6}$, Tetsuo KUNIEDA ${ }^{2}$ \\ ${ }^{1}$ Graduate School of Natural Science and Technology, Okayama University, Tsushima-naka, Kita-ku, Okayama 700-8530, Japan \\ ${ }^{2}$ Graduate School of Environmental and Life Science, Okayama University, Tsushima-naka, Kita-ku, Okayama 700-8530, Japan \\ ${ }^{3}$ Yoeneda Genotyping Laboratory, Takatsuki, Osaka, 569-1017, Japan \\ ${ }^{4}$ Faculty of Agriculture, Kagoshima University, Korimoto, Kagoshima 890-8580, Japan \\ ${ }^{5}$ Graduate School of Agricultural Science, Kobe University, Rokkodai, Nada-ku, Kobe 657-8501, Japan \\ ${ }^{6}$ Institute of Animal Science, Kawamuki, Shidara, Aichi 441-2423, Japan
}

\begin{abstract}
Kuchinoshima cattle is a breed of the unique feral cattle originated from grazing Japanese native cattle in Kuchinoshima island of Tokara Islands in Kagoshima prefecture during Meiji and Taisho periods. The distribution and frequencies of alleles of the genes associated with economical traits and hereditary disorders have been reported in populations of Japanese Black cattle that is a major beef cattle breed in Japan and Mishima cattle that is another Japanese native cattle breed in Mishima island, but those of Kuchinoshima cattle have not been reported. Therefore, we investigated the allelic distribution and frequencies of the genes associated with economical traits, hereditary disorders, and coat color to reveal genetic characteristic of Kuchinoshima cattle by comparison of the distributions among Kuchinoshima, Japanese Black, and Mishima cattle. By using 32 DNA samples collected from Kuchinoshima cattle, we genotyped NCAPG, FASN, SCD, and SREBP-1genes associated with economical traits including carcass weight and fatty acid composition, F11 gene responsible for factor XI deficiency, and $M C 1 R$ gene involved in coat color determination by PCR or PCR-RFLP assay and compared these results with those of Japanese Black and Mishima cattle. As a result, we found that while both $G$ and $T$ alleles of NCAPG locus were observed in the population of Japanese black cattle, the locus was fixed to $T$ allele in the populations of Kuchinoshima and Mishima cattle, and that while
\end{abstract}

連絡先 : 国枝哲夫 岡山大学大学院環境生命科学研究科

T 700-8530 岡山県岡山市北区津島中 1-1-1

(tkunieda@okayama-u.ac.jp)

2014 年 6 月 18 日受理 


\section{斯琴図雅ら}

both $T W$ and AR alleles of FASN locus were observed in Japanese black cattle, the locus was fixed to $A R$ allele in Kuchinoshima cattle and $T W$ allele in Mishima cattle. For the $S C D$ and $S R E B P-1$ loci, both $A$ and $V$ alleles of $S C D$ locus were observed in Japanese Black, Kuchinoshima, and Mishima cattle, and both $S$ and $L$ alleles $S R E B P-1$ locus were observed in Japanese Black and Mishima cattle but fixed to L allele in Kuchinoshima cattle. Furthermore, while both (+) and (-) alleles of F11 locus were observed in the population of Japanese black cattle, the locus was fixed to (+) allele in the populations of Kuchinoshima and Mishima cattle. Finally, we observed $E^{+}$and e alleles of $M C 1 R$ locus in Kuchinoshima cattle, while $E^{\mathrm{D}}$ and $E^{+}$allele but no e allele in Japanese Black cattle and only $E^{+}$allele in Mishima cattle were observed. These findings indicate that Kuchinoshima cattle comprises a population of Japanese native cattle possessing unique genetic characteristics different from those of Japanese Black and Mishima cattle, which has been formed under geographically isolated circumstance with relatively small population without influence of foreign breeds.

Key words: Kuchinoshima native cattle, Distribution and frequency of allele, Economical trait, Hereditary disorder

\section{要約}

口之島牛は鹿児島県卜カラ列島の口之島において、明治から大正期にかけて放牧されていた日本在来牛が野生化 した日本で唯一の野生化牛の集団である。これまでに、我が国の主要な肉用牛である黒毛和種や日本在来牛といわ れる見島牛等においては経済形質や遺伝性疾患に関する種々の遺伝子の遺伝子頻度と分布は明らかにされている が、口之島牛におけるそれらに関する報告は少ない。そこで、本研究では口之島牛の集団における経済形質、遺伝 性疾患および毛色に関与する遺伝子の対立遺伝子頻度と分布を調べ、それらを黒毛和種および見島牛の集団と比較 することで、口之島牛の集団の遺伝的特徵について検討した。32頭の口之島牛より採取されたDNAサンプルを用い、 脂肪酸組成や枝肉形質に関与することが報告されている NCAPG、FASN、SCD および SREBP-1 遺伝子、遺伝性疾 患の第 XI 因子欠乏症の原因遺伝子である F11、毛色に関与する MC1R 遺伝子について PCR 法あるいは PCR-RFLP 法により遺伝子型判定を行い、黒毛和種および見島牛の集団の結果と比較した。その結果、NCAPG 遺伝子につい ては、黒毛和種では $G$ および $T$ の両対立遺伝子が検出されたのに対し、口之島牛と見島牛では $T$ に固定され、 $F A S N$ 遺伝子については、黒毛和種では $T W$ および $A R$ の両対立遺伝子が検出されたのに対し、口之島牛では $A R に 、$ 見島牛では $T W$ に固定されていた。 $S C D$ 遺伝子については、黒毛和種、口之島牛、見島牛のいずれでも $A$ と $V$ の 両対立遺伝子が検出され、SREBP-1 遺伝子については、黒毛和種および見島牛では $S$ および $L$ の両対立遺伝子が検 出されたのに対し、口之島牛では $L$ に固定されていた。F11 遺伝子については、黒毛和種では (+) 抢よび (-) の両対 立遺伝子が検出されたのに対し、口之島牛、見島牛では $(+)$ に固定され、MC1R 遺伝子については、黒毛和種では $E^{D}$ および $E^{+}$対立遺伝子が検出され、口之島牛では $E^{+}$および $\mathrm{e}$ 対立遺伝子が検出され、見島牛では $E^{+}$対立遺伝子 に固定されていた。これらの結果より、口之島牛は他のウシの集団と地理的に隔離された環境で、小さな集団とし て維持されてきたこと等の理由により、黒毛和種や見島牛とは異なる遺伝的特徵を持つ集団を形成していると考え られた。

キーワード：口之島牛、在来牛、遺伝子頻度と分布、経済形質、遺伝性疾患

\section{緒言}

和牛は明治以降に日本の在来牛を外国品種と交配し て確立された日本の肉用牛であり、特に黒毛和種は我 が国の主要な肉用牛として用いられ、現在、和牛の飼 育総頭数の $90 \%$ 以上を占めている。一方で、外国品種 の影響を受けていない日本固有の在来種として特徴を 残しているのは、鹿児島県トカラ列島の口之島に生息 する口之島牛と山口県見島で飼育されている見島牛だ
けであり、見島牛は国の天然記念物に指定されている (Nagamine ら 2008)。一方、口之島牛は放牧されてい た牛が大正期に野生化された日本で唯一の野生化牛の 集団であり、見島牛とならんで日本在来牛としての特 徵を強く残していると考えられている（林田と野澤 1964; 印牧 2014)。その特徵は、黑毛和種に比べて体 格は非常に小さく、後駆がしまり腰骨幅と座骨幅が著 しく狭いという体格を有しており、毛色は黒、褐色の 
ほか、白斑などの変異を示している（印牧と安藤 2013 ; 印牧 印刷中)。これらの外見的特徽は、日本 において古来より飼育されていたウシが持つ遺伝的特 徵を残している可能性もあるため、口之島牛は遺伝資 源として貴重であると考えられている。同時に、近年 遺伝的多様性の減少が危惧されている黒毛和種 （Nomura ら 2001；Nishimaki ら 2013）の遺伝的多様性 を維持していく上での有用な遺伝資源となる可能性も ある。したがって、口之島牛集団の遺伝的特徴を調べ ることは、和牛の遺伝資源の保護においても重要であ ると考えられる。

一方、近年では家畜の経済形質や遺伝性疾患に関わ る多くの遺伝子が同定され、それらの遺伝子型を指標 とした選抜育種も行われている（Hirano ら 2000 ；Ohba ら 2000 ; Taniguchi ら 2004 ; Kunieda, 2005 ; Kunieda ら 2005 ; Hoash 5 2007; , Abe ら 2009, ; Setoguchi ら 2009）。それらの中でも黒毛和種の枝肉重量や脂肪酸 組成等の経済形質に関わる遺伝子であるNon-SMC Condensin I Complex, Subunit G (NCAPG)、Fatty Acid Synthase $(F A S N) 、$ Stearoyl-CoA Desaturase $(S C D)$ および Sterol Regulatory Element Binding Protein-1 (SREBP-1)、 遺伝性疾患である血液凝固第 XI 因子久乏症の原因遺 伝子であるFactor XI (F11)、毛色に関する Melanocortin-1 receptor $(M C 1 R)$ 遺伝子では、その遺伝 子型の判別法も確立されている。これまでに、黒毛和 種および見島牛の集団におけるこれらの経済形質、遺 伝性疾患および毛色等に関する遺伝子の対立遺伝子頻 度等は報告されているが（Sasazaki ら 2005 ；米田ら 2010 ; Matsuhashi ら 2011)、口之島牛の集団における これらの遺伝子の対立遺伝子頻度等の遺伝的特徵は一 部を除いてまだ明らかとされていない。そこで、本研 究では口之島牛の DNA サンプルを用い、 $N C A P G$ 、 $F A S N 、 S C D 、 S R E B P-1 、 F 11$ および $M C 1 R$ 遺伝子の遺 伝子型をPCR 法および PCR-RFLP 法により判定し、 黒毛和種および見島牛の結果と比較することで口之島 牛の遺伝的特徵について検討した。

\section{材料および方法}

名古屋大学大学院生命農学研究科附属フィールド科 学教育研究センター設楽フィールドで飼育されている 19 頭、および鹿児島大学農学部附属農場入来牧場で飼 育されている 13 頭の計 32 頭の口之島牛の DNA サン プル、財団法人動物繁殖研究所白老牧場に由来する見 島牛種雄牛 11 頭の DNA サンプル、岡山大学農学部附 属フィールド科学教育研究センター津高牧場に飼育さ
れている黒毛和種 45 頭の DNA サンプルを用いた。名 古屋大学の口之島牛集団は 1990 年に導入された雄 1 頭、雌 3 頭、1993 年に導入された雄 3 頭、雌 3 頭の計 雄 4 頭、雌 6 頭の個体に由来する集団であり（印牧と 安藤 2013)、鹿児島大学の口之島牛集団は 1995 年から 1997 に導入された雄 4 頭、雌 4 頭および導入年不明の 雄 3 頭、雌 1 頭の計雄 7 頭、雌 5 頭に由来している集 団である。

NCAPG、FASN、SCD、SREBP-1、F11 および MC1R の各遺伝子について、各集団のウシの血液、各種臓器、 毛根、あるいは凍結精液より定法にしたがって抽出さ れたゲノム DNA を用いたPCR 法により DNA の特定 の領域を増幅した。それぞれの PCR 反応に用いたプラ イマーの配列は Table 1 に示した。PCRの反応液は、 20ngのゲノム DNA、 $0.2 \mu \mathrm{M}$ のプライマー、 $0.2 \mu \mathrm{M}$ の dNTP、 $5 \times$ PCR buffer、0.5U の Taq ポリメラ - ゼ (Promega, USA) を含み、全体が 10ul となるように滅 菌水にて調整した。PCR 反応条件は、加熱変性温度 $94^{\circ} \mathrm{C}$ で 30 秒、Table 1 に示した各プライマーのアニー リング温度で MC1R については 60 秒、NCAPGについ ては 45 秒、それ以外については 30 秒、伸長温度 $M C 1 R$ については 60 秒、NCAPGについては 45 秒、 それ以外については 30 秒を 1 サイクルとして、 $N C A P G 、 M C 1 R$ については 40 回、それ以外について は 35 回繰り返し、最後に $72^{\circ} \mathrm{C}$ で 350 秒の伸長反応を 1 回行った。PCR 反応終了後、F11 および $S R E B P-1$ 遺 伝子について、増幅された PCR 産物を 3\% のアガロー スゲルを用いて TBE バッファー中にて $100 \mathrm{~V} て ゙ 30$ 分 電気泳動をした後、臭化エチジウム染色の後に紫外線 照射により可視化し、増幅断片の長さの違いにより遺 伝子型判定を行った。MC1R、SCD、NCAPG および $F A S N$ 遺伝子について、PCR 増幅産物を Table 1 に示し た各遺伝子に対応した特定の制限酵素を用いて消化し た後、同様に $3 \%$ のアガロースゲルにて電気泳動を行 い、制限酵素断片の長さの違いにより遺伝子型の判定 を行った。

統計解析には R プログラム (version2.15.1) を用いた。 集団間全体における各遺伝子型頻度の有意性検定は $\chi^{2}$ 検定を行い、その結果が有意である場合は各集団間に 対して $\chi^{2}$ 検定をおこなった。各遺伝子の遺伝子型と 遺伝子頻度の間のハーディー・ワインベルグ平衡に対 する有意性検定には $\chi^{2}$ 検定を用いた。

\section{結果と考察}

$N C A P G$ は細胞分裂における染色体の凝集に関わる 
Table1. Primer sequences, fragment lengths, annealing temperatures, and restriction enzymes for genotyping.

\begin{tabular}{|c|c|c|c|c|}
\hline Gene & Primer sequence $\left(5^{\prime}-3^{\prime}\right)$ & Length & Temp** & Enzyme \\
\hline \multirow[t]{2}{*}{$N C A P G$} & ATTTAGGAAACGACTACTGG & $129 \mathrm{bp}$ & 51 & \\
\hline & ATTTGTATTCTCTTATTATCATC & $66,63 \mathrm{bp} *$ & & Tsp509I \\
\hline \multirow[t]{2}{*}{$S C D$} & GTGTCCTGTTGTTGTGCTTCATCCTGCC & 197bp & 60 & \\
\hline & AATATTCTCTCGGGGGTTGATGGTCTTG & $156,41 \mathrm{bp} *$ & & NcoI \\
\hline \multirow[t]{2}{*}{ FASN } & CTCACTGTCTGTCCCACAGG & $243 b p$ & 60 & \\
\hline & GCCTTTGGAGGGCTTCTTAG & $149,94 \mathrm{bp} *$ & & HhaI \\
\hline \multirow[t]{2}{*}{$S R E B P-1$} & CCACAACGCCATCGAGAAACGCTAC & $348,432 \mathrm{bp}$ & 65 & \\
\hline & GGCCTTCCСТGACCACCCAACTTAG & & & \\
\hline \multirow[t]{2}{*}{ F11 } & TCACATCTCAATATGTGCTTCTGC & $95,110 \mathrm{bp}$ & 60 & \\
\hline & TCTACGATGTCCAGTTCTTCTCC & & & \\
\hline \multirow[t]{2}{*}{$\operatorname{MC1R}\left(E^{+}, E^{D}\right)$} & TGGTGAGTCTCGTGGAGAACG & $214 \mathrm{bp}$ & 65 & \\
\hline & TCGATGACATTGTCCAACTGCTGC & $149,65 \mathrm{bp} *$ & & MspA1I \\
\hline \multirow[t]{2}{*}{$\operatorname{MC1R}(E, e)$} & ATCTGCTGCCTGGCTGTGTCTGACT & $219 b p$ & 65 & \\
\hline & GGCGTAGAAGATGGAGATGTAGCGG & $139,80 \mathrm{bp} *$ & & MspI \\
\hline
\end{tabular}

*Italicized letters indicate lengths of digested fragments.

**Annealing Temperature

タンパク質であり、本遺伝子の第 9 エクソンに拈ける イソロイシンからメチオニンへのアミノ酸置換を引き 起こす 1,326 番目の塩基の $T$ から $G$ への置換が肉牛の 枝肉重量と関連することが報告されている (Eberlein ら 2009 ; Setoguchi ら 2009)。この変異について制限醩素 Tsp509I を用い、PCR-RFLP 法により遺伝子型を調べた ところ、黒毛和種では、 $G / G 、 G / T 、 T / T$ の個体がそれ ぞれ 1、18、26であるのに対し、口之島牛および見島 牛では全ての個体が $T / T$ であり、 $G / G$ 执よび $G / T$ の個 体は存在しなかった。したがって、黒毛和種、口之島牛、 見島牛の集団ではそれぞれ、 $G$ 対立遺伝子の頻度は 0.222、0、0、T 対立遺伝子の頻度は $0.778 、 1 、 1$ であり、 本遺伝子の対立遺伝子頻度は黒毛和種と口之島牛、見 島牛の集団の間で大きく異なり、口之島牛、見島牛で は $T$ に固定されていることが明らかとなった (Table.2)。

$F A S N$ は脂肪酸合成を制御する醅素であり、本遺伝 子の第 34 エクソンに打りるスレニン（T）からアラ ニン（A）のアミノ酸置換を引き起こす 16,024 番目の 塩基の A から $\mathrm{G} へ の$ 置換、扩よびトリプトファン（W）
からアルギニン（R）へのアミノ酸置換を引き起こす 16,039 番目の塩基の $\mathrm{T}$ から $\mathrm{C}$ への置換が、黒毛和種の 脂肪に㧍ける脂肪酸組成に関連していることが報告さ れている (Abe ら 2009)。この 16,024 番目の塩基置換に ついて制限酵素HhaIを用いた PCR-RFLP 法により遺 伝子型を調べたところ、TW/TW、TW/AR、AR/AR の 個体はそれぞれ、黒毛和種で 23、19、3、口之島牛で 0、 0、32、見島牛で、11、0、0であった。したがって、 黒毛和種、口之島牛、見島牛の集団ではそれぞれ、 $T W$ 対立遺伝子の頻度は $0.722 、 0 、 1 、 A R$ 対立遺伝子 の頻度は $0.278 、 1 、 0$ であり、本遺伝子の対立遺伝子 頻度は黒毛和種と口之島牛、見島牛の集団の間で大き く異なり、口之島牛では $A R$ に、見島牛では $T W$ に固 定されていることが明らかとなった (Table.3)。なお、 黒毛和種に打ける対立遺伝子頻度は、これまでの報告 と大きな違いはなかった（Matsuhashi ら 2011）。

$\mathrm{SCD}$ は脂肪細胞で飽和脂肪酸（SFA）を一価不飽和 脂肪酸 (MUFA) に変換する酵素であり、本遺伝子の第 5 エクソンに扔けるバリン（V）からアラニン（A）へ

Table 2. Genotype and allele frequencies of $N C A P G$

\begin{tabular}{lclllll}
\hline \multirow{2}{*}{ Breed } & \multirow{2}{*}{$\begin{array}{c}\text { No. of } \\
\text { cattle }\end{array}$} & \multicolumn{2}{c}{ Genotype frequencies } & & \multicolumn{2}{c}{ allele frequencies } \\
\cline { 3 - 6 } & 45 & & $G / T$ & $T / T$ & $G$ & $T$ \\
\hline Japanese Black $^{\mathrm{a}}$ & 45 & $1(0.022)$ & $18(0.400)$ & $26(0.578)$ & 0.222 & 0.778 \\
Kuchinoshima $^{\mathrm{b}}$ & 32 & $0(0)$ & $0(0)$ & $32(1)$ & 0 & 1 \\
Mishima $^{\mathrm{b}}$ & 11 & $0(0)$ & $0(0)$ & $11(1)$ & 0 & 1 \\
\hline
\end{tabular}

${ }^{\mathrm{a}-\mathrm{b}}$ Mean different superscripts letters in the same column with differ significantly $(\mathrm{P}<0.05)$ Desirable allele of $N C A P G$ is $G$ type. 


\section{ロ之島牛における各種遺伝子の対立遺伝子頻度}

Table 3. Genotype and allele frequencies of FASN

\begin{tabular}{|c|c|c|c|c|c|c|}
\hline \multirow[t]{2}{*}{ Breed } & \multirow{2}{*}{$\begin{array}{l}\text { No. of } \\
\text { cattle }\end{array}$} & \multicolumn{3}{|c|}{ Genotype frequencies } & \multicolumn{2}{|c|}{ allele frequencies } \\
\hline & & $T W / T W$ & $T W / A R$ & $A R / A R$ & $T W$ & $A R$ \\
\hline Japanese Black $^{\mathrm{a}}$ & 45 & $23(0.511)$ & $19(0.422)$ & $3(0.067)$ & 0.722 & 0.278 \\
\hline Kuchinoshima $^{\mathrm{b}}$ & 32 & $0(0)$ & $0(0)$ & $32(1)$ & 0 & 1 \\
\hline Mishima $^{c}$ & 11 & $11(1)$ & $0(0)$ & $0(0)$ & 1 & 0 \\
\hline
\end{tabular}

のアミノ酸置換を引き起こす 878 番目の塩基の $\mathrm{T}$ から $\mathrm{C}$ の置換が脂肪における脂肪酸組成に関連しているこ とが報告されている (Taniguchi ら 2004)。この変異につ いて制限酵素 NcoI を用いて PCR-RFLP 法により調べ たところ、黒毛和種における $A / A 、 A / V 、 V / V$ の個体 は黒毛和種で 25、15、5 であった。名古屋大学の口之 島集団ではこれまでに、 $A / A 、 A / V 、 V / V$ の個体が存在 することがすでに報告されているが（印牧と安藤 2013)、今回これらに加えて新たに鹿児島大学の集団 の $S C D$ の遺伝子型を調べたところ、両者をあわせた口 之島牛の集団では $A / A 、 A / V 、 V / V$ の個体はそれぞれ 9、 16、7であった。また、これまでに見島牛の集団では $A / A 、 A / V 、 V / V$ の個体はそれぞれ9、2、0 であること が報告されている（米田ら 2010）。したがって、黒 毛和種における $S C D$ の $A$ および $V$ 対立遺伝子頻度は 0.722 および 0.278 であるのに対して、口之島牛では 0.531 および 0.469 であり、見島牛では 0.909 および 0.091 であり、本遺伝子の対立遺伝子頻度は黒毛和種と口之 島牛、見島牛の集団では大きな違いはないことが明ら かとなった (Table.4)。なお、黒毛和種における対立遺 伝子頻度は、これまでの報告と大きな違いはなかった (Matsuhashi ら 2011)。

$S R E B P-1$ 遺伝子は脂肪酸組成などに関与する転写因 子であり、本遺伝子の第 5 イントロンにおける $84 \mathrm{bp}$ の欠損の有無により $L$ 型および $S$ 型が存在し、不飽和 脂肪酸の含有量に関連することが報告されている (Hoashi ら 2007)。この変異を PCR 法により調べたとこ ろ、黒毛和種における $S / S 、 S / L 、 L / L$ の個体はそれぞ
れ黒毛和種で 2、14、29、口之島牛では 0、0、31 であっ た。また、これまでに見島牛の集団では $S / S 、 S / L 、 L /$ $L$ の個体は2、8、1 であることが報告されている（米 田ら 2010)。したがって、黒毛和種における $S R E B P-1$ の $S$ および $L$ 対立遺伝子頻度は 0.200 および 0.800 であるのに対して、口之島牛では 0 および 1 、見 島牛では 0.545 および 0.455 であり (Table.5)、口之島牛 の集団では $L$ に固定されていた。なお、黒毛和種にお ける対立遺伝子頻度は、これまでの報告に比べて $L$ が 高い傾向が見られた（Matsuhashi ら 2011）。

血液凝固不全による出血性の遺伝性疾患である第 XI 因子欠乏症はヒトや各種の動物で報告され、ウシでは、 黒毛和種、ホルスタイン種に発生が報告されている。 黒毛和種の第 XI 因子久乏症では、その原因はF11 遺 伝子の第 9 エクソンにおける 15 塩基の挿入であるこ とが明らかとされており (Kunieda ら 2005)、挿入の有(-) 無 $(+)$ の PCR 法による遺伝子診断法が確立されている。 そこで PCR 法によりF11 の遺伝子型を調べたところ、 黒毛和種では+/+、+/-、-/-の個体はそれぞれ34、10、

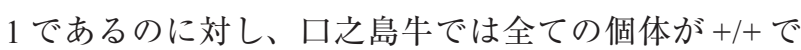
あり、+/-および-/-の個体は存在しなかった。また、 これまでに見島牛の集団でも 11 個体全てが+/+であり、 +/- および-/-の個体は存在しないことが報告されてい る（米田ら 2010）。したがって、黒毛和種、口之島牛、 見島牛の集団ではそれぞれ、正常 $(+)$ 対立遺伝子の頻 度は 0.867、1、1、変異 (-) 対立遺伝子の頻度は 0.133、0、 0 であり、口之島牛、見島牛では変異対立遺伝子は存 在せず、 $(+)$ に固定されていることが明らかとなった

Table 4. Genotype and allele frequencies of $S C D$

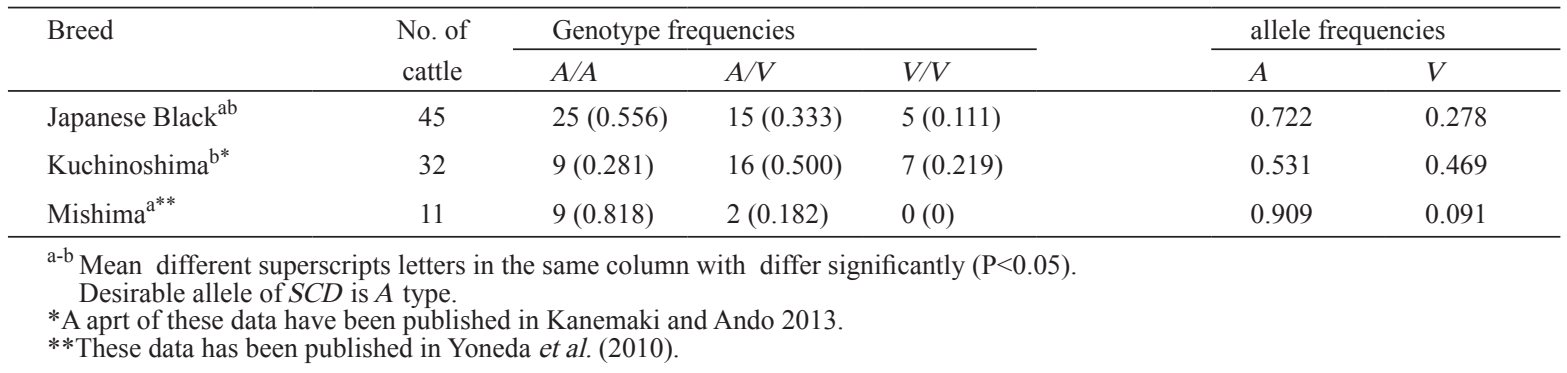


Table 5. Genotype and allele frequencies of SREBP-1

\begin{tabular}{|c|c|c|c|c|c|c|}
\hline \multirow[t]{2}{*}{ Breed } & \multirow{2}{*}{$\begin{array}{l}\text { No. of } \\
\text { cattle }\end{array}$} & \multicolumn{3}{|c|}{ Genotype frequencies } & \multicolumn{2}{|c|}{ allele frequencies } \\
\hline & & $S / S$ & $S / L$ & $L / L$ & $S$ & $L$ \\
\hline Japanese Black $^{\mathrm{a}}$ & 45 & $2(0.044)$ & $14(0.311)$ & $29(0.644)$ & 0.200 & 0.800 \\
\hline Kuchinoshima $^{\mathrm{b}}$ & 31 & $0(0)$ & $0(0)$ & $31(1)$ & 0 & 1 \\
\hline Mishima $^{\mathrm{c}^{* *}}$ & 11 & $2(0.182)$ & $8(0.727)$ & $1(0.091)$ & 0.545 & 0.455 \\
\hline
\end{tabular}

${ }^{\mathrm{a}-\mathrm{c}}$ Mean different superscripts letters in the same column with differ significantly $(\mathrm{P}<0.05)$.

Desirable allele of $S R E B P-1$ is $S$ type.

**These data has been published in Yoneda et al. (2010).

Table 6. Genotype and allele frequencies of $F 11$

\begin{tabular}{|c|c|c|c|c|c|c|}
\hline Breed & $\begin{array}{l}\text { No. of } \\
\text { cattle }\end{array}$ & \multicolumn{3}{|c|}{ Genotype frequencies } & \multicolumn{2}{|c|}{ allele frequencies } \\
\hline Japanese Black $^{\mathrm{a}}$ & 45 & $34(0.756)$ & $10(0.222)$ & $1(0.022)$ & 0.867 & 0.133 \\
\hline Mishima $^{\mathrm{ab}^{* *}}$ & 11 & $11(1)$ & $0(0)$ & $0(0)$ & 1 & 0 \\
\hline
\end{tabular}

${ }^{\mathrm{a}-\mathrm{b}}$ Mean different superscripts letters in the same column with differ significantly $(\mathrm{P}<0.05)$

Mutant allele of F11 is - type.

**These data has been published in Yoneda et al. (2010).

(Table.6)。なお、今回調べた黒毛和種の集団における (-) 対立遺伝子の頻度は、これまでの報告より低い傾向が 見られた（Ohba ら 2008）。

$M C 1 R$ は哺乳類の毛色に関わる下垂体ホルモンのメ ラノコルチンに対する受容体であり、本遺伝子のロイ シンからプロリンへのアミノ酸置換を引き起こす 298 番目の塩基の $\mathrm{T}$ から $\mathrm{C}$ の置換が毛色の黒 $\left(E^{D}\right)$ と黒褐 色 $\left(E^{+}\right)$の違いに関わり、また フレームシフト変異 を引き起こす 311 番目の塩基の欠失が毛色の黒あるい は黒褐色と褐色（e）の違いに関わることが報告されて いる (Klungland ら 1995)。これらの変異を制限酵素 MspA1I およびMspI を用いた PCR-RFLP 法により $E^{D}$ 、 $E^{+}$および $\mathrm{e}$ の遺伝子型判定を行ったところ、黒毛和種 の集団では $E^{D} / E^{D} 、 E^{D} / E^{+} 、 E^{+} / E^{+}$の個体はそれぞれ 10、19、15 であり、 $E^{D / e} 、 E^{+} / \mathrm{e}$ および $\mathrm{e} / \mathrm{e}$ の個体は 存在しなかった。また、名古屋大学の口之島集団では これまでに、e と $E^{D}$ あるいは $E^{+}$対立遺伝子が存在す ることが報告されているが（印牧と安藤 2013）、今回、 名古屋大学の集団に加えて鹿児島大学の集団も加え、 かつ $E^{D}$ と $E^{+}$を区別することで、口之島牛の集団では
$E^{D} / E^{D} 、 E^{D} / E^{+} 、 E^{D / e}$ は存在せず、 $E^{+} / E^{+} 、 E^{+} / \mathrm{e}$ および e/ e の個体はそれぞれ 4、17、10であることが明らか となった。また、これまでに見島牛の集団では $E^{D を}$ 持つ個体は存在せず全て $E^{+} / E^{+}$であることが報告され ているが、eについては調べられていなかったが（米 田ら 2010)、今回、eについても調べた結果、e を持つ 個体は存在しないことが確認され、全ての個体は $E^{+} /$ $E^{+}$であることが明らかとなった。したがって、黒毛和 種における $M C 1 R$ の $E^{D} 、 E^{+}$、および $\mathrm{e}$ 対立遺伝子の 頻度は 0.443、0.557、0であるのに対して、口之島牛 では 0、0.403、0.597であり、見島牛では $0 、 1 、 0$ であっ た (Table.7)。口之島牛におけるこれらの MC1Rの遺伝 子型は実際の毛色と一致していた。なお、黒毛和種の 集団中には、e も低頻度で存在することが知られてい るが、今回調べた黒毛和種の集団には e は検出されな かった。

口之島に実際に野生化状態で生息する口之島牛は、 正確な数は不明であるが、現時点でおおよそ70 頭前 後の集団であると推測されており（印牧印刷中）、 歴史的にも 30 頭から 100 頭程度の個体よりなる集団

Table 7. Genotype and allele frequencies of $M C 1 R$

\begin{tabular}{|c|c|c|c|c|c|c|c|c|c|c|}
\hline \multirow[t]{2}{*}{ Breed } & \multirow{2}{*}{$\begin{array}{c}\text { No. of } \\
\text { cattle }\end{array}$} & \multicolumn{6}{|c|}{ Genotype frequencies } & \multicolumn{3}{|c|}{ allele frequencies } \\
\hline & & $E^{D} / E^{D}$ & $E^{D} / E^{+}$ & $E^{+} / E^{+}$ & $E^{D / e}$ & $E^{+} / e$ & $\mathrm{e} / \mathrm{e}$ & $E^{D}$ & $E^{+}$ & e \\
\hline Japanese Black ${ }^{\mathrm{a}}$ & 44 & $10(0.227)$ & $19(0.432)$ & $15(0.341)$ & $0(0)$ & $0(0)$ & $0(0)$ & 0.443 & 0.557 & 0.000 \\
\hline Kuchinoshima ${ }^{b^{*}}$ & 31 & $0(0)$ & $0(0)$ & $4(0.129)$ & $0(0)$ & $17(0.548)$ & $10(0.323)$ & 0 & 0.403 & 0.597 \\
\hline Mishima $^{\mathrm{c}^{* *}}$ & 11 & $0(0)$ & $0(0)$ & $11(1)$ & $0(0)$ & $0(0)$ & $0(0)$ & 0 & 1 & 0 \\
\hline
\end{tabular}

${ }^{a-c}$ Mean different superscripts letters in the same column with differ significantly $(\mathrm{P}<0.05)$.

*A aprt of these data have been published in Kanemaki and Ando (2013).

**A aprt of these data has been published in Yoneda et al. (2010). 
を構成していると考えられている（印牧と安藤 2013）。 今回の遺伝子型の解析に用いた 32 個体は、名古屋大 学の集団が 1990 年代に口之島にて捕獲された雄 4 頭、 此 6 頭の個体に由来し、鹿児島大学の集団がやはり 1990 年代に捕獲された雄 7 頭、雌 5 頭由来している。 したがって、数十頭の野生化牛集団のうちの計 22 頭 に由来することから、本研究に用いたサンプルは口之 島牛に生息する野生化牛の遺伝的特性を反映している ものと考えられる。本研究によるこれらサンプルを用 いた遺伝子型の調査の結果、脂肪酸組成や枝肉重量等 の経済形質、遺伝性疾患、毛色に関与する遺伝子の口 之島牛の集団における対立遺伝子頻度が明らかとな り、それらを黒毛和種および見島牛の集団の対立遺伝 子頻度と比較した結果、口之島牛集団の遺伝的特徵と、 これらの牛集団の関係について以下のことが示唆され た。

今回調べた遺伝子の中で、 $N C A P G$ の $G$ 対立遺伝子、 $F 11$ の (-) 対立遺伝子および $M C 1 R$ の $E^{D}$ 対立遺伝子は 黒毛和種の集団中においてある程度の頻度で検出され たのに対し、口之島牛および見島牛の集団では、 $N C A P G$ では $T$ 対立遺伝子、F11 では $(+)$ 対立遺伝子に 固定され、 $M C 1 R$ では $E^{D}$ 対立遺伝子は存在しないこ とが明らかとなった。このことは、 $N C A P G$ の $G$ 対立 遺伝子、F11 の (-) 対立遺伝子および $M C 1 R$ の $E^{D}$ 対立 遺伝子はもともと日本の在来牛には存在せず黒毛和種 の系統成立の過程で導入され交雑された外来品種との 交配に由来している可能性を示唆している。しかし一 方で、口之島牛の集団および見島牛の集団はいずれも 比較的小さな閉鎖された集団であることから、これら の対立遺伝子は日本の在来牛には存在していたが、口 之島牛および見島牛の集団の成立の過程でのボトル ネック効果や創始者効果、あるいは長期的に他の集団 とは隔離された状態で維持された過程での遺伝的浮動 等により特定の対立遺伝子が消失した可能性も否定で きない。また、長年にわたる黒毛和種の育種の過程で、 枝肉重量が多い方向へ、毛色をより黒い方向へと選抜 された結果、もともとの在来牛に低い頻度で存在して いた $N C A P G$ の $G$ 対立遺伝子および $M C 1 R$ の $E^{D}$ 対立 遺伝子の頻度が増加した可能性も考えられた。

一方 FASN、SCD および SREBP-1、および MC1R の $E^{+}$および $\mathrm{e}$ 対立遺伝子については、口之島牛と見島牛 の集団においてもそれぞれの対立遺伝子が検出される ことから、日本の在来牛にこれらの対立遺伝子はもと もと存在していたものと考えられる。したがって、 $F A S N$ の $T W$ 対立遺伝子が口之島牛の集団で、 $A R$ 対立
遺伝子が見島牛の集団で、SREBP-1 の $S$ 対立遺伝子が 口之島牛の集団で、および $M C 1 R$ の 対立遺伝子が見 島牛の集団で検出されなかったことは、これらの集団 の成立の過程でのボトルネック効果や創始者効果ある いは長期的に他の集団とは隔離された状態で維持され た過程での遺伝的浮動等により対立遺伝子の片方が消 失した可能性が考えられた。

日本の在来牛には古来より黒色とともに褐色の毛色 が存在することはこれまでに古文書等に記載されてい る。MC1Rの $\mathrm{e}$ 対立遺伝子は、これまでに黒毛和種を 含む多くの品種における褐色の毛色に関わることが報 告されているが、今回、口之島牛の褐色の毛色も外国 品種と同じく $M C 1 R$ 遺伝子の 311 番目の塩基の欠失を 持つ e 対立遺伝子に起因することが明らかとなったこ とから、この $\mathrm{e}$ 対立遺伝子は家畜としてのウシの歴史 の中で、外国品種と日本在来牛が分岐した以前からウ シの集団に存在していた古い変異であることが示唆さ れた。

今回調べた $N C A P G 、 F A S N 、 S C D 、 S R E B P-1 、 F 11$ および $M C 1 R$ の計 6 遺伝子については、黒毛和種の集

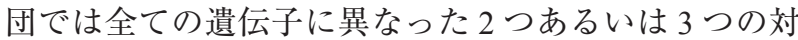
立遺伝子が検出されたのに対し、口之島牛の集団では、 $N C A P G 、 F A S N 、 S R E B P-1$ およびF11 の 4 遺伝子にお いて、見島牛の集団では $N C A P G 、 F A S N 、 F 11$ および $M C 1 R$ の 4 遺伝子において単一の対立遺伝子に固定さ れていた。これまでに、名古屋大学の口之島牛の集団 における遺伝的多様生の調査の結果、調べた 9 システ 厶の血液型のうちの 4 システムにおいて、また 52 の マイクロサテライトマーカーのうち 36 マーカーにお いて多型が確認されたことから、口之島牛は集団が小 さく、他の集団から隔離されて閉鎖的に維持されてい るにも関わらず、遺伝的多様性が高い可能性があるこ とが報告されている(印牧と安藤 2013)。今回の結果は、 この報告とは異なり口之島牛の集団の遺伝的多様性は 低い可能性を示している。しかし、マイクロサテライ トマーカーや血液型が高い多型性を示す中立的な遺伝 マーカーであるのと異なり、今回調べた遺伝子は経済 形質や、遺伝性疾患、毛色に関わる遺伝子であり、表 現型に与える影響も大きく選択、選抜に対して中立的 とはいえないことが、これらの結果に影響している可 能性も考えられる。一方で、主要組織適合性遺伝子複 合体（MHC）DRB3 遺伝子座については、口之島牛の 集団ではほぼ全ての個体が単一の対立遺伝子に固定さ れていることが明らかにされており（間ら 私信）、 今後、多様なマーカーを調べることで口之島牛の遺伝 
的多様性を正確に評価することが必要と考えられた。

\section{謝辞}

本研究の一部は日本学術振興会科学研究費補助金、 文部科学省特別経費「低炭素社会と食の安全・安心を 統合した環境生命学的研究」および農林水産省「新 たな農林水産政策を推進する実用技術開発事業」の助 成を受けて行われた。黒毛和種のサンプリングに協力 いただいた岡山大学農学部附属フィールド科学教育研 究センター津高牧場の野久保隆技術職員に感謝しま す。

\section{文献}

Abe T, Saburi J, Hasebe H, Nakagawa T, Misumi S, Nade T, Nakajima H, Shoji N, Kobayashi M, Kobayashi E. 2009. Novel Mutations of the FASN Gene and Their Effect on Fatty Acid Composition in Japanese Black Beef. Biochemical Genetics, 47:397-411.

Eberlein A, Takasuga A, Setoguchi K, Pfuhl R, Flisikowski K, Fries R, Klopp N, Fürbass R,Weikard R, Kühn C. 2009. Dissection of genetic factors modulating fetal growth in cattle indicates a substantial role of the nonSMC condensin I complex, subunit G (NCAPG) gene. Genetics, 183:951-964.

林田重幸・野澤謙。1964. 卜カラ群島における牛。 日本在来家畜調査団報告, 1:24-30.

Hirano T, Kobayashi N, Itoh T, Takasugi A, Nakamaru T, Hirotsune S, Sugimoto Y. 2000.Null mutation of PCLN-1/Claudin-16 results in bovine chronic interstitial nephritis. Genome Research, 10: 659-663.

Hoashi S, Ashida N, Ohsaki H, Utsugi T, Sasazaki S, Taniguchi M, Oyama K, Mukai F, Mannen H. 2007. Genotype of bovine sterol regulatory element binding protein-1 (SREBP-1) is associated with fatty acid composition in Japanese black cattle. Mammalian Genome, 18:880-886.

印牧美佐生. 2014. 口之島野生化牛. 動物遺伝育種 学研究, 42: 39-47.

印牧美佐生 - 安藤洋. 2013. 名古屋大学で維持 - 育成 された口之島野生化牛集団の特性. 在来家畜研 究会報告, 26: 81-93.

Klungland H, Våge DI, Gomez-Raya L, Adalsteinsson S, Lien S. 1995. The role of melanocyte-stimulating hormone $(\mathrm{MSH})$ receptor in bovine coat color determination. Mammalian Genome, 6:636-639.
Kunieda T. 2005.Identification of genes responsible for hereditary diseases in Japanese beef cattle. Animal Science Journal, 76: 525-533.

Kunieda M, Tsuji T, Abbasi AR, Khalaj M, IkedaM, Miyadera K, Ogawa H, Kunieda T. 2005. An insertion mutation of the bovine $F 11$ gene is responsible for factor XI deficiency in Japanese Black cattle. Mammalian Genome, 16:383-389.

Matsuhashi T, Maruyama S, Uemoto Y, Kobayashi N, Mannen H, Abe T, Sakaguchi S, Kobayashi E. 2011. Effects of bovine fatty acid synthase, stearoyl-coenzyme A desaturase, sterol regulatory element-binding protein 1 , and growth hormone gene polymorphisms on fatty acid composition and carcass traits in Japanese Black cattle. Animal Science Journal, 89:12-22.

Nagamine Y, Nirasawa K, Takahashi H, Sasaki O, Ishii K, Minezawa M, Oda S, Visscher PM, Furukawa T. 2008. Estimation of the time of divergence between Japanese Mishima Island cattle and other cattle populations using microsatellite DNA markers. Journal of Heredity, 99: 202-207.

Nishimaki T, Ibi T, Tanabe Y, Miyazaki Y, Kobayashi N, Matsuhashi T, Akiyama T, Yoshida E, Imai K, Matsui M, Uemura K, Watanabe N, Fujita T, Saito Y, Komatsu T, Yamada T, Mannen H, Sasazaki S, Kunieda T. 2013. The assessment of genetic diversity within and among the eight subpopulations of Japanese Black cattle using 52 microsatellite markers. Animal Science Journal, 84:585-591.

Nishimura S, Watanabe T, Mizoshita K, Tatsuda K, Fujita T, Watanabe N, Sugimoto Y, Takasuga A. 2012. Genomewide association study identified three major QTL for carcass weight including the PLAG1-CHCHD7 QTN for stature in Japanese Black cattle. BMC Genetics, 13:40.

Nomura T, Honda T, Mukai F. 2001. Inbreeding and effective population size of Japanese Black cattle. Journal of Animal Science, 79: 366-370.

Ohba Y, Kitagawa H, Kitoh K, Sasaki Y, Takami M, Shinkai Y, Kunieda T. 2000. A deletion of the paracellin-1 gene is responsible for renal tubular dysplasia in cattle. Genomics, 68: 229-236.

Ohba Y, Takasu M, Nishii N, Takeda E, Maeda S, Kunieda T, Kitagawa H. 2008. Pedigree analysis of factor XI deficiency in Japanese black cattle. Journal of 
Veterinary Medical Science, 70:297-299.

Ohsaki H, Tanaka A, Hoashi S, Sasazaki S, Oyama K, Taniguchi M, Mukai F, Mennen H. 2009. Effect of SCD and SREBP genotyoes on fatty acid composition in adipose tissue of Japanese Black cattle herds. Animal Science Journal, 80:225-232.

Sasazaki S, Usui M, Mannen H, Hiura C, Tsuji S.2005. Allele frequencies of the extension locus encoding the melanocortin-1 receptor in Japanese and Korean cattle. Animal Science Journal, 76:129-132.

Setoguchi K, Furuta M, Hirano T, Nagao T, Watanabe T, Sugimoto Y, Takasuga A. 2009. Cross-breed comparisons identified a critical $591-\mathrm{kb}$ region for bovine carcass weight QTL $(\mathrm{CW}-2)$ on chromosome 6 and the Ile-442-Met substitution in NCAPG as a positional candidate. BMC Genetics, 10:43.

Taniguchi M, Utsugi T, Oyama K, Mannen H, Kobayashi M, Tanabe Y, Ogino A, Tsuji S. 2004. Genotype of stearoylCoA desaturase is associated with fatty acid composition in Japanese Black cattle. Mammalian Genome, 14:142-148.

米田一裕 ·渡辺望 - 国枝哲夫. 2010. 見島牛におけ る遺伝性疾患、毛色、経済形質に関わる遺伝子座 の対立遺伝子の分布. 動物遺伝育種学研究, 38:13-19. 